\title{
Miranda
}

Revue pluridisciplinaire du monde anglophone /

Multidisciplinary peer-reviewed journal on the English-

speaking world

$4 \mid 2011$

Samuel Beckett : Drama as philosophical endgame?

\section{Eleutheria-Notes on Freedom between Offstage and Self-reference}

Shimon Levy

\section{(2) OpenEdition}

\section{Journals}

Electronic version

URL: http://journals.openedition.org/miranda/2019

DOI: 10.4000/miranda.2019

ISSN: 2108-6559

\section{Publisher}

Université Toulouse - Jean Jaurès

Electronic reference

Shimon Levy, "Eleutheria-Notes on Freedom between Offstage and Self-reference", Miranda [Online],

4 | 2011, Online since 24 June 2011, connection on 16 February 2021. URL: http://

journals.openedition.org/miranda/2019 ; DOl: https://doi.org/10.4000/miranda.2019

This text was automatically generated on 16 February 2021.

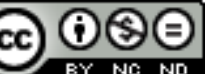

Miranda is licensed under a Creative Commons Attribution-NonCommercial-NoDerivatives 4.0 International License. 


\title{
Eleutheria-Notes on Freedom between Offstage and Self-reference
}

\author{
Shimon Levy
}

1 Samuel Beckett's works have long and profoundly been massaged by numerous philosophical and semi-philosophical views, methods and "isms", ranging from Descartes, Geulincx and Malebranche to existentialism à la Sartre and Camus, to logical positivism following Frege, Wittgenstein and others-to name but a few. P. J. Murphy rightly maintains that "the whole question of Beckett's relationship to the philosophers is pretty obviously in need of a major critical assessment". ${ }^{1}$ In many, if not most studies, "a philosophy" has been superimposed on the piece in an attempt to prove that the work behaves in accordance with, or at least follows, some main notions of "the philosophy". Beckett was well versed in the philosophies of his time; indeed, he inserted quite a number of real and mock philosophical odds and ends in his writing, but finally, rather than follow Wittgenstein's famous "Whereof one cannot speak, thereof one must be silent." ("Wovon man nicht sprechen kann, darüber muss man schweigen.") ${ }^{2}$ Beckett seems to have made meticulous and consequent efforts to write [about] the un-writeable. This is clearly evident in his later prose, such as Stirrings Still or Worstward Ho, where the piece ends in an obvious paradox: "Whence no farther. Best worse no farther. Nowhow less. Nowhow worse. Nowhow naught. Nohow on. Said nowhow on."3

2 Whereas Beckett's prose sometimes gains from the intervention of an external theory-literary or philosophical-his drama, since it was initially intended for performance (live in the theatre, preserved as six radio plays, five television plays, and one film ${ }^{4}$ ), is less receptive to non-medium oriented notions of interpretation, since performing the piece, first and foremost, exposes it to practical rather than theoretical factors.

3 In the following notes I therefore contend that Beckett's drama is better explored with the help of interpretative notions ensuing from the particular performance factors of the piece itself, and only then, more generally, from the entire volume of Beckett's dramatic corpus. I intend to rely on what for me at least, but also for many other 
Beckett directors, proved to be the playwright's superb sensitivity, originality and profound understanding of "theatricality". Whereas many of Beckett's philosophical critics prefer to avoid his stage instructions, Xerxes Mehta, director and theoretician in the "practical" sense of having experienced the subject of his theatrical enquiries, says that in Beckett's plays "stage directions, which solicit the images, are the play."

Having already tried an organic approach to Beckett's plays ${ }^{6}$, here I relate mainly to Beckett's first play, Eleutheria. The reasons for this are both practical and theoretical. My way to understanding Beckett's plays has been paved, first of all, through translating all of them into $\mathrm{Hebrew}^{7}$, thus forcing myself to touch each and every word while rendering them into a language for which I relatively rarely need a dictionary. I translated Eleutheria last-and was pleasantly surprised to realize to what degree and how exquisitely Beckett inserted stylistic, thematic and "medium-oriented" fractals, dramatic and theatrical seeds that developed and transformed in many of his later plays. The two main notions I shall address are self-reference and offstage. They ensue from Beckett's works rather than being imposed on them.

As late as the summer of 1951 Beckett was still interested in mounting a production of Eleutheria, "as one of the plays that ushered in a new era in avant-garde French theatre". Knowlson relates to a number of details that exorcise episodes from Beckett's life as well as profound attitudes to life and its meaning in Eleutheria, adding that Beckett had considered the piece "seriously flawed", and had acknowledged that "Ionesco, Adamov and Genet have moved on in the meantime". Retrospectively, Eleutheria can be considered a wonderful theatre workshop in which many motifs, and more importantly, typical Beckettian dramatic techniques used in his later plays, can clearly be detected.

6 While working on the original French as well as taking a look at the American English version by Michael Brodsky and the British English one by Barbara Wright ${ }^{9}$, I realized, to begin with, how fascinating this first Beckett play is, especially regarding his highly innovative self-referential devices. In this respect at least I disagree with Mel Gussow, who thought that if "Waiting for Godot is revolutionary; Eleutheria is evolutionary" [Theatre Review, 25-06-95]. Eleutheria may at times be overly explicit or even somewhat laborious, as Beckett himself probably thought, but its dramatic text nevertheless offers a surprising, indeed revolutionary number of highly coherent meta-theatrical devices harnessed to the main theme - freedom.

7 Rather than adding a few more secondary insights to the intra-Beckettian allusions found by Knowlson, Buning and others about pre-figurations in Eleutheria, of motifs developed in his later works (and "post-figurations" of his older ones in his novels and novellas), I focus on his revealing stage instructions, which primarily relate to space. Consequently, I also connect the notion of offstage with a hermeneutical circle of Author, Actors, and Audience in their self-referential aspect, in which (I argue) Beckett designed a delicate balance between Creator, Medium and Recipient, as the very foundation of the theatrical situation.

8 Space is the main non-verbal theatrical element of Eleutheria. Beckett, in more than three pages, describes:

...a split set, with two very different decors juxtaposed. Hence there are two simultaneous actions: the main action and the marginal action. The latter is silent, apart from a few short phrases, the stage business there being confined to the vague attitudes and movement of a single character. In fact it is not so much a place 
of action as a site, which is often empty.

The text in Eleutheria is almost exclusively concerned with the main action. The marginal action is for the actor to determine, within the limits of the indications in the following note.

[...] The two rooms share the whole width of the rear wall as well as the same floor, but when they pass from Victor to his family they become domesticated and respectable. Like the water from the open sea becoming the water in the harbour. The theatrical effect of this dualistic space, then, should be produced less by the transition than by the fact that Victor's room takes up three quarters of the stage, and by the flagrant discrepancy between the furniture on either side. ${ }^{10}$

The two spaces obviously represent two different modes of life, and the dramatic action of the play is well activated through the change of setting. However, this set is neither a symbol nor even a "stage metaphor". In his first full-length play, Beckett, retrospectively, prepares his individual usage of offstage for his plays to come.

Offstage in many, especially modern, plays is both a technique and a "content", a medium as well as a message, a theatrically active element that manages to escape the paradox of "expressing the inexpressible", and to present void, nothingness and emptiness (not to mention vaguer and more emotionally charged notions such as "seclusion", "loneliness", "being there" etc.) without refuting them, since after all, there's an audience sitting there watching, listening and somehow taking part in the action. As a shadowy doppelgänger, offstage in Eleutheria is clearly designed to function as a major rather than "a marginal" partner. Indeed, as we learn throughout the threeact action, marginality itself (with or without quotation marks) turns out to be the dominant "message".

11 Moreover, in response to Marius Buning's perception of Via Negativa in Beckett's writing ${ }^{11}$, some of Beckett's works reveal a unique brinkmanship between an intellectually skeptical rejection of religiosity and an equally present yearning for the "beyond", whatever "it" may be-spirituality, perhaps ${ }^{12}$. Notions of the "beyond" hover in and above Beckett's drama like a restlessly reappearing Godot, or rather the child in the play, about whom Beckett told his friend Gottfried Büttner: "He is not from here" ${ }^{13}$. The frequent appearances of many dramatic characters and phenomena no less than their central quality in the plays, indicate that Beckett was greatly interested in exploring what may be "out there", or alternatively and equally unattainably, "deep inside". This asymptotic tendency towards the "divine" is already manifest in Eleutheria. If, in many of his future plays, "holy" may mean a numinous attitude towards divine beings ${ }^{14}$, then Beckett's drama is not really "holy". But if "holy" is at least allowed to mean an artistic attempt to grasp essences that are neither physical nor even mental, then some of Beckett's plays come fairly close to "holy".

Eleutheria, not least because of the "freedom" of its name (an almost blatant giveaway), and the ardent, lonely (and only semi-ironically referred to as "decrepit") quest that Victor sets out on towards his spiritual freedom, is primarily expressed through and by offstage. Side by side with his snide rejection of theological, mostly Christian clichés of the Holy, it should be noted that many of the theologies known to Beckett accept that "The Path" (here obviously the theatrical path) can be regarded as "spiritual", namely, not satisfyingly explicable (to Beckett) by means of material, psychological or other purely rational theories.

13 *Beckett seems to achieve a considerable degree of Victor's (and quite likely his own) freedom through the very creative theatrical process itself. Despite the fact that Victor 
never says a word about God, God's various angels or saints or any religious experience whatsoever, his quest should nevertheless still be regarded as spiritual. This quest for spiritual freedom is not only dearly paid for by severing family, society and romantic ties, but also totally misunderstood by the other characters. Perhaps Beckett did not want to fall into the simplistic trap of explaining what spirituality "is". Spiritual freedom, he might imply, must come from within (like Winnie's song in Happy Days), it is never negotiable. It cannot be talked about, because as soon as one tries to it risks losing its uncompromising individuality. Since, as we have seen, words in Beckett's play are sometimes likely to betray their meaning, offstage does the work for Victor, absent yet very much there-like freedom.

In Eleutheria text and space as such-rather than what the text says or what space signifies-are often presented as dramatic opposites. Whereas the verbal text in Eleutheria is often witty, and at times even overtly funny though sometimes intentionally trivial, so as to underline Victor's space, inner and external, offstage is strongly juxtaposed with the verbal text and is always somber and severe. Victor's space, a wonderfully theatrical metaphor for his character, is beautifully described, "Like the water from the open sea becoming the water in the harbour." ${ }^{15}$ In this image Beckett reveals his "positive" treatment of Victor's quest more than he conceals it in what the "others" say about him and, perhaps, suggests how difficult spiritual freedom is when one cannot differentiate between "waters of the [clean] open sea" and "waters in the harbour" of family, bourgeois being and a love life.

Beckett maintains a particularly delicate balance between his explicit demand for the "unobtrusive" quality of the marginal action on the one hand, and its obviously contrary effect on the other. "Most of the time it is only a question of a site and of a person in stasis", he specifies, but whoever in the audience pays attention to exactly this will surely be overwhelmed by the "negative" power of a passive-aggressive theatricality, according to Buning's description of Beckett's "negative theology"16, or indeed, by the active, intensive employment of offstage. Because offstage too needs theatrical means to draw attention to itself, Beckett asks of his Victor character to pace, to look at the audience, "to be lying down and motionless" etc., "but most of the time he stays where he is, either motionless or restless" ${ }^{17}$. Victor's minimal movement is certainly meant to underline his space as "not so much a place of action as a site, which is often empty."

According to the hermeneutical circle of author, actor and audience, Beckett the person/author is strongly implied through Victor and even explicitly so in the text: "Samuel Beke, Beke... he must be a cross between a Jew from Greenland and a peasant from the Auvergne" [136]. Victor/Beckett's refusal to disclose his reasons for his reclusive behavior, or rather for maintaining his quest for spiritual freedom, often recurs as a main motif in Beckett's later plays, beginning with Godot himself, on to the "mole" (the same term used in Eleutheria) in Radio II. Is it probably Beckett himself who is represented as C in Theatre II. In Cascando the "story" motif is connected with the "extrication" process and with life itself: "he opens nothing, he has nothing to open, it's in his head". ${ }^{18}$ More explicitly the Victor theme appears in Cascando in:

They say, That is not his life, he does not live on that. They don't see me, they don't see what my life is, they don't see what I live on, and they say, That is not his life, he does not live on that. [Pause.] I have lived on it... till I'm old. Old enough. ${ }^{19}$ 
Moreover, the torturer Chouchi in Eleutheria, perhaps representing the audience or an academic or a theatre critic, is the persona who tries throughout Beckett's plays to extricate some truth from the fugitive, freedom-seeking protagonist. Only in Ohio Impromptu and perhaps in What Where, reader and listener, torturer and tortured finally become one..$^{20}$ In Eleutheria, though, Victor manages to barely escape his torturer(s) by telling them: "I told you a story to get you to leave me in peace"21 — which is likely to be what Beckett does to his readers and audiences, although on the other hand: "You may prattle away to your last breath and still the one... thing remaining unsaid that can give you back your darling solitude, we know. But this much is sure: the more you say the greater your chances". ${ }^{22}$

This last line may well be ironical, of course, but it is meta-theatrical and selfreferential just the same. Billy Whitelaw, in her autobiography says: "this short play proved to be the most telling event of my professional life" ${ }^{23}$. As a director of some of Beckett's plays, strongly supported by the biographies and memories of actors who worked with Beckett, like, David Warrilow, Billie Whitelaw and others, I learned that without truly putting one's self into Beckett's often very open and vacant characters, in themselves proxies of himself and "his people", as he called his characters, no really successful acting can take place in Beckett's roles. Mehta too supports this rational as well as highly intuitive notion: "the performer does not know whether he or she is an actor, a character or some form of transparency for an unknowable other" 24 . Beckett, as Mehta rightly claims, locks the spectator to his own consciousness (175). This may be ascribed to Beckett's consistently repeated references to freedom, Eleutheria, Freedom, as an un-re-presentable urge, because it must come as a thrust "from the inmost" ${ }^{25}$. It can therefore only be presented.

A few Beckett actors deal relatively peacefully with their confinement to urns, ashbins, rocking chairs etc., and to playing blind, paralyzed, strapped or prostate-suffering characters-physically. Fewer still manage to keep Beckett's humor and courage in their staged agonies, probably so designed by the author to help them feel the role physically. Fewer, however, manage to convey to the audience or to their onstage partners, the all important sense that whatever happens to their lines and stage instructions, really happens to them. If they do, such a production has a fair chance of being enriched with an aura of a spiritual quest. This aura always hovers in this unique presence in absentia, offstage, always there, hardly noticeable unless intensive attention is paid to it.

Whether the audience, to briefly relate to the third element in the hermeneutical circle in Beckett's plays, is aware of this, is another question. In Eleutheria, however, its representative is actually invited onstage as "spectator", in a role often more serious than his entertaining remarks might seem to the audience. The "audience" becomes an implied character in Beckett's later plays. Didi and Gogo are also Lucky and Pozzo's audience, and vice versa. A similar on-stage audience-actors device is used for Hamm and Clov in Endgame, as well as for Winnie and Willie in Happy Days, including Winnie's story about the two people who looked at her stuck in her mound. Some Beckett plays end with an almost explicit gesture to the audience: the handkerchief in Theatre II, Willie's hand stretched toward Winnie, the auditor in Not I, whose "four brief movements" ${ }^{26}$ show a helpless compassion, thus inviting the audience to feel as outsiders regarding what goes on inside "Not I". 
Finally Victor, a distant kin of Melville's Bartleby, Dostoyevsky's Prince Mishkin, and other passive dramatic and literary characters, perhaps Michel, the glazier's son, will follow in his footsteps, turning his "emaciated back on humanity" ${ }^{27}$. If we are to believe him, Victor's problem is that Freedom is to see yourself dead, an impossibility in life, therefore called here "histrionics", as he also says (151). In a brilliant stage instruction, following the ones about Victor's movements in the marginal action, Beckett foreshadows Victor's turning his back on humanity and describes a passage as coming to an abrupt end, "as if overcome by a feeling of fatigue and fatuity" (140), in line with the opening note of Act III: "Krap family side swallowed up by orchestra pit" (118), where both space and acting-style/action fall into offstage, inertia, passivity and nothingness, in fact hypostatizing this very issue.

Freedom can hardly be forced even on oneself, though Victor tries hard enough and not at all on others. All that Beckett can do, and does in Eleutheria, is to deal with this most important theme in his creative life through meta-theatricality and offstage, leaving people free to respond as they wish, freely. Perhaps only theatre can "say" and "not say" important things. Perhaps Eleutheria is not Beckett's best play, but it certainly is one of his most interesting ones. Its "flaws", even more than some of its revolutionary achievements, are highly revealing, at least insofar as to how Beckett was coping with his creative if not personal freedom.

\section{NOTES}

1. Murphy, P.J. "Beckett and the Philosophers." In John Pilling (ed.). The Cambridge Companion to Beckett. Cambridge: CUP, 1994, 222.

2. Wittgenstein, Ludwig. Tractatus Logico-Philosophicus. London: Harcourt/Kegan Paul, $1922,75$.

3. Beckett, Samuel. Nohow On, NY: Grove Press, 1996, 116.

4. Produced by the BBC, 1957-1976. Distributed by the British Library. Also, by Voices International, 1986-89, distributed by Evergreen Review.

5. Mehta, Xerxes. "Ghosts." In Lois Oppenheimer (ed.) Directing Beckett. Ann Arbor: The University of Michigan, 1994, 184.

6. Levy, Shimon. Samuel Beckett's Self-Referential Drama-The Sensitive Chaos. Brighton \& Portland: Sussex Academic Press, 2002.

7. Levy, Shimon. Translation and introduction. Samuel Beckett, The Complete Dramatic Works [Hebrew]. Tel Aviv: Safra \& Assaph/Plays, 2009.

8. Knowlson, James. Damned to Fame. London: Bloomsbury, 1996, 364.

9. Beckett, Samuel. Eleutheria. Translated by Barbara Wright. London: Faber \& Faber, 1996.

10. Eleutheria 5. 
11. Buning, Marius. "The 'Via Negativa' and its First Stirrings in Eleutheria." In Marius Buning, Matthijs Engelberts and Onno Kosters (eds.) Samuel Beckett Today/Aujourd'hui 9, 43-54.

12. Levy, Shimon. "On and Offstage, Spiritual Performatives in Beckett's Drama." In Marius Buning, Matthijs Engelberts \& Onno Kosters (eds.) Samuel Beckett Today/ Aujourd'hui 9, 17.

13. Büttner, Gottfried. Samuel Beckett's Novel Watt. Philadelphia: University of Pensilvania, 1984, 153.

14. Ruby Cohn, Xerxes Mehta and others relate to Beckett's "ghosts." E.G. Xerxes Mehta, "Ghosts." in Lois Oppenheimer (ed.) Directing Beckett. Ann Arbor: The University of Michigan, 1994, 184.

15. Eleutheria, 5.

16. Buning, 47.

17. Eleutheria, 7.

18. Beckett, Samuel. The Complete Dramatic Works. London: Faber \& Faber, 1986, 300.

19. Beckett 1986, 300.

20. Beckett 1986, 446.

21. Eleutheria, 150.

22. Beckett 1986, 281.

23. Whitelaw, Billy ...Who He? London: Hodder \& Stoughton, 1995132.

24. Mehta, 179.

25. Beckett 1986, 155.

26. Beckett 1986, 376.

27. Eleutheria, 70.

\section{ABSTRACTS}

In this article, Shimon Levy argues that the critical concepts used in the interpretation of Beckett's writings for the stage should emanate from the experience of the performance rather than be imposed, ready-made, from the outside. Thus, he opposes theatricality to theoretical extrapolations on the text. Relying on his experience as a stage director and translator of Beckett, he proposes to observe two determining factors in the constitution of Beckett's playwrighting: self-reference and the off-stage. For that purpose, he concentrates on Beckett's first play: Eleutheria.

Dans cet article, Shimon Levy suggère que les concepts critiques propices à l'approche de l'œuvre dramatique de Beckett doivent être tirés de l'expérience de sa représentation sur scène et non empruntés à des systèmes de réflexion déjà construits. Il oppose ainsi la théâtralité aux extrapolations théoriques. En s'appuyant sur son expérience de la mise en scène et de la traduction de l'auteur, il se propose d'étudier deux facteurs déterminants dans la constitution de 
la dramaturgie Beckettienne : l'auto-référence et le hors-scène. Il en démontrera l'importance en s'appuyant sur la première pièce de Beckett : Eleutheria.

INDEX

Mots-clés: sacré, hors-scène, espace, auto-référence, liberté, Eleutheria, Oh les beaux jours, fin de partie, Cascando

Keywords: dramatic techniques, holy, off-Stage, space, self-reference, freedom, Eleutheria, Happy Days, endgame, Cascando

\section{AUTHORS}

\section{SHIMON LEVY}

Professor, Translator and Director University of Tel Aviv 